Jurnal Ilmu Sosial dan Pendidikan (JISIP)

Vol. 5 No. 3 Juli 2021

Terakreditasi Peringkat 5 (No. SK: 85/M/KPT/2020)

e-ISSN : 2656-6753, p-ISSN: 2598-9944

DOI: 10.36312/jisip.v5i3.2261 /http://lejournal.mandalanursa.org/index.php/JISIP/index

\title{
FUNGSI KOMUNIKASI DALAM PENGAMBILAN KEPUTUSAN PADA DINAS PEMADAM DAN KEBAKARAN KOTA BIMA
}

\author{
Adilansyah \\ Program Studi Ilmu Administrasi Negara Sekolah Tinggi Ilmu Sosial dan Ilmu Politik (STISIP) Mbojo \\ Bima \\ Email : mhan_imoet@yahoo.com
}

\begin{tabular}{l}
\hline Article Info \\
\hline Article history: \\
Article Reseived : 26 July 2021 \\
Publication: 31 July 2021
\end{tabular}

Kata Kunci:

karakter peduli sosial, pembelajaran IPS

\begin{abstract}
Abstrak
Rumusan masalahnya sebagai berikut: 1) Bagaimana penelusuran dan pengumpulan data atau informasi sebagai proses pengambilan keputusan pada Dinas Pemadam Kebakaran Kota Bima ? 2. Bagaimana analisis data sebagai proses pengambilan keputusan pada Dinas Pemadam Kebakaran Kota Bima ? 3. Bagaimana penetapan keputusan sebagai proses pengambilan keputusan pada Dinas Pemadam Kebakaran Kota Bima ? 4. Bagaimana evaluasi keputusan sebagai proses pengambilan keputusan pada Dinas Pemadam Kebakaran Kota Bima? Penelitian ini bertujuan: 1) Untuk mengetahui penelusuran dan pengumpulan data atau informasi sebagai proses pengambilan keputusan pada Dinas Pemadam Kebakaran Kota Bima .2) Untuk mengetahui analisis data sebagai proses pengambilan keputusan pada Dinas Pemadam Kebakaran Kota Bima 3). Untuk mengetahui penetapan keputusan sebagai proses pengambilan keputusan pada Dinas Pemadam Kebakaran Kota Bima .4). Untuk mengetahui evaluasi keputusan sebagai proses pengambilan keputusan pada Dinas Pemadam Kebakaran Kota Bima. Guna pengklasifikasian penelitian, banyak istilah yang digunakan : ada yang menyebutnya tipe, sifat, dan yang lainnya menyebut jenis penelitian, dan dalam penelitian ini penulis menggunakan istilah jenis penelitian. Dalam penelitian ini jenis penelitian yang digunakan yaitu penelitian deskriptif. Menurut Sugiyono (2007:6), "Penelitian deskriptif adalah penelitian yang dilakukan terhadap variabel mandiri, yaitu tanpa membuat perbandingan, atau menghubungkan dengan variabel yang lain."Deskriptif dimaksudkan di mana penulis akan menguraikan dan menggambarkan serta menganalisis tentang fungsi informasi dalam pengambilan keputusan pada Dinas Pemadam Kebakaran Kota Bima .
\end{abstract}

Keyword

social care character, social studies learning

\begin{tabular}{l}
\hline Corresponding Author: \\
Adilansyah \\
Program Studi Ilmu Administrasi \\
Negara Sekolah Tinggi Ilmu Sosial dan \\
Ilmu Politik(STISIP) Mbojo Bima \\
Email : mhan_imoet@yahoo.com \\
\hline \hline
\end{tabular}

This is an open access article under the Lisensi Creative Commons Atribusi-BerbagiSerupa 4.0 Internasional 


\section{PENDAHULUAN}

\subsection{Latar Belakang Masalah}

Bencana merupakan suatu peristiwa atau serangkaian peristiwa yang mengancam dan mengganggu kehidupan dan penghidupan masyarakat sebagaimana dapat disebabkan baik oleh faktor alam, faktor non alam, maupun faktor manusia yang mengakibatkan timbulnya korban jiwa manusia, kerusakan lingkungan, kerugian harta benda, dan dampak psikologis (UU RI No.24 tahun 2007 tentang Peenanggulangan Bencana). Menurut Arahan Kebijakan Mitigasi Bencana Perkotaan (Kahaba, 2015 dalam Laporan Pendahuluan Updating Peta Rawan Kebakaran Kota Bima 2021) potensi bencana yang terjadi dapat dikelompokkan menjadi dua yaitu potensi bahaya utama (main hazard) dan potensi bahaya ikutan (collateral hazard). Bahaya kebakaran pada dasarnya dapat disebabkan oleh dua faktor yaitu faktor alam (natural hazard) dan faktor kelalaian manusia (man made hazard).

Kebakaran adalah suatu reaksi oksidasi eksotermis yang berlangsung dengan cepat dari suatu bahan bakar yang disertai dengan timbulnya api atau penyalaan. Bencana kebakaran merupakan bencana serius bagi perkotaan. Hal tersebut dikerenakan berkaitan dengan jumlah korban maupun kerugian yang ditimbulkan akibat dari bencana tersebut. Bencana kebakaran dapat merugikan secara nasional dikarenakan mengganggu produktivitas nasional dan dapat menurunkan kesejahteraan masyarakat.

Kasus kebakaran pada umumnya sering terjadi di lokasi dengan tingkat kepadatan aktivitas yang terbilang sangat tinggi sehingga diperlukan kewaspadaan dari masyarakat akan bahaya kebakaran yang dapat mengakibatkan kerugian baik material maupun jiwa. Fenomena kebakaran yang terjadi di wilayah perkotaan sangat dipengaruhi korelasi antara bangunan gedung, tingkat aktivitas kawasan serta kondisi eksisting kawasan seperti kawasan permukiman kumuh (slums area), permukiman liar (squatter) hingga kawasan industri yang kurang tertata

\subsection{Rumusan Masalah}

Berdasarkan uraian dari latar belakang mengenai sistem administrasi perkantoran tidak terlepas dari permasalahan yang penulis angket dalam penelitian ini sebagai berikut:

Berdasarkan latar belakang masalah yang diuraikan di atas yang menjadi pokok masalah dalam pembahasan penelitian ini dapat dirumuskan sebagai berikut:

1. Bagaimana penelusuran dan pengumpulan data atau informasi sebagai proses pengambilan keputusan pada Dinas Pemadam Kebakaran Kota Bima?

2. Bagaimana analisis data sebagai proses pengambilan keputusan pada Dinas Pemadam Kebakaran Kota Bima?

3. Bagaimana penetapan keputusan sebagai proses pengambilan keputusan pada Dinas Pemadam Kebakaran Kota Bima?

4. Bagaimana evaluasi keputusan sebagai proses pengambilan keputusan pada Dinas Pemadam Kebakaran Kota Bima?

\subsection{Tujuan dan Kegunaan Penelitian}

\subsubsection{Tujuan Penelitian}

a. Untuk mengetahui penelusuran dan pengumpulan data atau informasi sebagai proses pengambilan keputusan pada Dinas Pemadam Kebakaran Kota Bima .

b. Untuk mengetahui analisis data sebagai proses pengambilan keputusan pada Dinas Pemadam Kebakaran Kota Bima

c. Untuk mengetahui penetapan keputusan sebagai proses pengambilan keputusan pada Dinas Pemadam Kebakaran Kota Bima .

d. Untuk mengetahui evaluasi keputusan sebagai proses pengambilan keputusan pada Dinas Pemadam Kebakaran Kota Bima . 


\subsection{Fokus Penelitian}

Fokus penelitian adalah konsep dimana berisi pengertian atau definisi konsep tersebut, aspek / dimensi / komponen / bentuk / gejala dan sebagainya dari konsep tersebut yang nantinya akan dijadikan indikator dari konsep tersebut, faktor-faktor yang mempengaruhi, dan sebagainya (Moleong, 1999 : 27).

Fokus penelitian memuat rincian pernyataan tentang cakupan atau topik-topik pokok yang akan diungkap/digali dalam penelitian ini. Apabila digunakan istilah rumusan masalah, fokus penelitian berisi pertanyaan-pertanyaan yang akan dijawab dalam penelitian dan alasan diajukannya pertanyaan. Pertanyaan-pertanyaan ini diajukan untuk mengetahui gambaran apa yang akan diungkapkan di lapangan. Pertanyaan-pertanyaan yang diajukan harus didukung oleh alasan-alasan mengapa hal tersebut ditampilkan.

Menurut Moleong (1999:55), fokus dasarnya adalah masalah yang bersumber dari pengalaman penelitian atau melalui pengetahuan yang bersumber dari pengalaman peneliti. Melalui pengetahuan yang diperolehnya, melalui kepustakaan ilmiah atau kepustakaan. Penentuan fokus penelitian memiliki dua tujuan yaitu: a. Penentuan fokus membatasi studi yang berarti bahwa dengan adanya fokus penentuan tempat menjadi layak. b. Penentuan fokus secara efektif menetapkan kriteria inklusi-inklusi untuk menyaring informasi yang masuk. Mungkin data cukup menarik, tetapi jika dipandang tidak relevan maka data itu tidak dipakai (Moleong, 1999:27).

\section{LANDASAN TEORI}

\subsection{Beberapa Pengertian}

\subsubsection{Pelaksanaan Fungsi}

Fungsi adalah kegiatan pokok yang dilakukan dalam suatu organisasi atau lembaga. Fungsi adalah jabatan atau kedudukan (Badudu dan Sutan dalam A. Gaffar, 2002:412).

Simandjuntak (A. Gaffar, 2002:3) mengemukakan pengertian atau makna fungsi sebagai berikut : "Fungsi adalah besaran yang berhubungan atau besaran yang berubah."

Musanef (A. Gaffar, 2002:10) menjelaskan, "Yang dimaksud dengan fungsi adalah sesuatu yang harus dijalankan dan merupakan aktivitas/aktivitas utama sebagai bagian atau sumbangan kepada organisasi secara keseluruhan atau bagian yang tertentu."

Siagian (George S. Odiorne, 2002:155) mengemukakan, "Secara singkat dapat dikatakan bahwa fungsi adalah perincian dari tugas pokok. Tugas pokok suatu Departemen merupakan derivation daripada fungsi-fungsi pemerintah karena suatu Departemen mempunyai tugas pokok dan fungsi untuk melakukan sebagian tugas pokok pemerintah sebagai keseluruhan.”

Dari beberapa definisi tersebut, maka dapat disimpulkan bahwa fungsi adalah pengaruh yang diharapkan dari seseorang dalam dan antar hubungan sosial tertentu; dan fungsi tersebut berlangsung bilamana seseorang melaksanakan hak-hak dan kewajiban-kewajiban sesuai dengan statusnya.

Atau dengan kesimpulan lain, fungsi menandakan suatu jabatan dalam sebuah organisasi yang menggambarkan akan tugas dan fungsinya.

\subsubsection{Pengertian Komunikasi}

Davis (Hafid Cangara, 2011:28), mengemukakan bahwa Secara umum pengertian komunikasi adalah proses pengiriman (sending) dan penerimaan (receiving) pesan atau berita (informasi) antara dua individu atau lebih dengan cara yang efektif sehingga pesan yang dimaksud dapat dipahami.

A. Winnet (Hafid Cangara, 2011:87) mendefinisikan komunikasi sebagai bentuk peralihan maksud, sebuah proses untuk memberikan maksud melalui serangkaian tahapan atau aktivitas kepada penerima. 
Jadi, secara umum secara umum pengertian komunikasi adalah proses pengiriman (sending) dan penerimaan (receiving) pesan atau berita (informasi) antara dua individu atau lebih dengan cara yang efektif sehingga pesan yang dimaksud dapat dipahami.

\subsubsection{Pengertian Pengambilan Keputusan}

Harahap (Hafid Cangara, 2011:87), mengemukakan "Pengambilan keputusan adalah proses memilih satu alternatif dari beberapa alternatif yang ada."

Salusu (M. Karjadi, 1997:47), mengemukakan bahwa "Pengambilan keputusan adalah: proses memilih sesuatu alternatif cara bertindak dengan metode yang efisien setuju situasi. Proses itu untuk menemukan dan menyelesaikan masalah organisasi."

Pernyataan ini menegaskan bahwa pengambilan keputusan memerlukan suatu seri tindakan, memerlukan beberapa langkah. Dapat saja langkah-langkah itu terdapat dalam pikiran seseorang yang sekaligus menjadinya berpikir sistematis.

Siagian (M. Karjadi, 1997:47), "Pengambilan eputusan adalah: suatu pendekatan yang sistematis itu menyangkut pengetahuan mengenai hakikat daripada masalah yang dihadapi itu, pengumpulan fakta dan data yang relevan dengan masalah yang dihadapi, analisa masalah dengan mempergunakan fakta dan data, mencari alternatif pemecahan, menganalisis setiap alternatif sehinga diketemukan altenatif yang paling rational, penilaian daripada hasil yang dicapai sebagai akibat daripada

\section{METODE PENELITIAN}

Sebagai sebuah karya ilmiah, maka konsekuensi yang harus dipertangungjawabkan obyektivitasnya, maka dalam upaya pengumpulan data yang diperlukan dalam penulisan Penelitian ini penulis melakukan rangkaian kegiatan dengan mengacu pada kerangka metode penelitian berturut-turut sebagai berikut.

\section{Jenis Penelitian}

Guna pengklasifikasian penelitian, banyak istilah yang digunakan : ada yang menyebutnya tipe, sifat, dan yang lainnya menyebut jenis penelitian, dan dalam penelitian ini penulis menggunakan istilah jenis penelitian.

Dalam penelitian ini jenis penelitian yang digunakan yaitu penelitian deskriptif. Menurut Sugiyono (2007:6), "Penelitian deskriptif adalah penelitian yang dilakukan terhadap variabel mandiri, yaitu tanpa membuat perbandingan, atau menghubungkan dengan variabel yang lain."

Deskriptif dimaksudkan di mana penulis akan menguraikan dan menggambarkan serta menganalisis tentang fungsi informasi dalam pengambilan keputusan pada Dinas Pemadam Kebakaran Kota Bima.

\section{PEMBAHASAN HASIL PENELITIAN}

Dalam pembahasan hasil penelitian, biasanya merupakan jawaban atas pertanyaan yang diajukan pada bagian rumusan masalah (Bab I). Oleh karena itu, pada bagian ini penulis akan menganalisis sejumlah masalah yang telah diajukan, diawali dengan kegiatan mengumpulkan datadata atau informasi-informasi di lapangan dengan menanyakan informan (sampel) yang telah ditentukan sebagaimana dijelaskan pada Bab I.

Sesuai dengan masalah yang diajukan pada Bab I, maka dalam penelitian ini rumusan masalah yang akan dianalisis atau dibahas kaitan dengan proses pengambilan keputusan pada Dinas Pemadam Kebakaran Kota Bima. Sehubungan dengan proses pengambilan keputusan pada Dinas Pemadam Kebakaran Kota Bima, sebagaimana yang akan dibahas dalam penelitian ini, maka terdapat 4 (empat) variabel yang akan dibahas, yaitu : pertama, penelusuran dan pengumpulan data atau informasi; kedua, analisis data; ketiga, penetapan keputusan; dan keempat, evaluasi keputusan. 
Untuk mengetahui, bagaimana proses dalam pengambilan keputusan Kota di Dinas Pemadam Kebakaran Kota Bima , akan dijelaskan satu persatu sebagai berikut.

\subsection{Penelusuran dan pengumpulan data atau informasi}

Terdapat 4 (empat) sub-variabel yang hendak diuji pada variabel penelusuran dan pengumpulan data atau informasi yaitu: pertama, penataan data atau informasi; kedua, penyederhanaan data atau informasi; ketiga, pengelompokkan data atau informasi; dan keempat, penabulasian data atau informasi.

Untuk mengetahui mengenai penelusuran dan pengumpulan data atau informasi dalam pengambilan keputusan, akan dijelaskan satu persatu sebagaimana sajian wawancara berikut ini. Kegiatan penelusuran dan pengumpulan data atau informasi dalam pengambilan keputusan yang pertama yaitu penataan data atau informasi. Untuk mengetahui penataan data atau informasi dalam proses pengambilan keputusan pada rapat di Dinas Pemadam Kebakaran Kota Bima , akan terlihat sebagaimana sajian hasil wawancara berikut.

Hasil wawancara dengan Bapak Ambo selaku Staf pada Dinas Pemadam Kebakaran Kota Bima sebagai berikut:

"Ada beberapa hal yang perlu dilakukan kaitan dengan pengambilan keputusan pada saat rapat, yang salah satunya penataan data atau informasi dalam proses pengambilan keputusan. Dimana kita perl, menjaring aspirasi setiap peserta rapat berupa usulan atau program yang akan dilaksanakan" (Wawancara, Mei 2021).

Berdasarkan pada hasil wawancara tersebut, maka tampak bahwa keadaan tanggapan informan tentang penataan data atau informasi dalam proses pengambilan keputusan pada rapat di Dinas Pemadam Kebakaran Kota Bima mayoritas atau dominan informan menjawab sangat sesuai. Jenis penataan data atau informasi dalam proses pengambilan keputusan pada rapat yang kedua yaitu penyederhanaan data atau informasi Berarti dengan demikian, penataan data atau informasi dalam proses pengambilan keputusan pada rapat di Dinas Pemadam Kebakaran Kota Bima dinilai sangat sesuai.Untuk mengetahui penyederhanaan data atau informasi dalam proses pengambilan keputusan pada rapat di Dinas Pemadam Kebakaran Kota Bima , akan terlihat sebagaimana sajian wawancara berikut.

Penelusuran dan pengumpulan data atau informasi dalam proses pengambilan keputusan pada rapat yang ketiga yaitu pengelompokkan data atau informasi.Untuk mengetahui pengelompokkan data atau informasi dalam proses pengambilan keputusan pada rapat di Dinas Pemadam Kebakaran Kota Bima , akan terlihat sebagaimana sajian hasil wawancara berikut.

Hasil wawancara dengan Bapak Dedi, BA, salah seorang Staf Dinas Pemadam Kebakaran Kota Bima sebagai berikut: Informasi merupakan hasil pembentukan, pengorganisasian atau pengubahan data di mana dengan cara itu dapat meningkatkan pengetahuan penerimanya. Artinya, data-data itu harus dikelompok-kelompokkan" (Wawancara, Mei 2021).

Berdasarkan pada hasil wawancara tersebut, maka tampak bahwa keadaan tanggapan informan tentang pengelompokkan data atau informasi dalam proses pengambilan keputusan pada rapat di Dinas Pemadam Kebakaran Kota Bima mayoritas atau dominan informan menjawab sangat sesuai. Berarti dengan demikian, pengelompokkan data atau informasi dalam proses pengambilan keputusan pada rapat di Dinas Pemadam Kebakaran Kota Bima dinilai sangat sesuai. Penelusuran dan pengumpulan data atau informasi yang keempat yaitu penabulasian data atau informasi. 
Untuk mengetahui penabulasian data atau informasi dalam proses pengambilan keputusan pada rapat di Dinas Pemadam Kebakaran Kota Bima , akan terlihat sebagaimana sajian hasil wawancara berikut. Hasil wawancara dengan Bapak Drs. Arifuddin Muhammad, Kepala Dinas Damkar Kota Bima sebagai berikut: "Data-data yang telah dihimpun oleh Dinas Damkar Kota Bima selanjutnya akan ditabulasikan lagi. Menurut pengamatan saya, mereka telah menyiapkan format yang besar untuk menabulasi semua data yang ada. Agar data akuratif. Maksudnya bahwa informasi hendaknya bebas dari kekeliruan-kekeliruan komputasi dan lain-lain" (Wawancara, Mei 2021).

Berdasarkan pada hasil wawancara tersebut, maka tampak bahwa keadaan tanggapan informan tentang penabulasian data atau informasi dalam proses pengambilan keputusan pada rapat di Dinas Pemadam Kebakaran Kota Bima mayoritas atau dominan informan menjawab sangat sesuai. Berarti dengan demikian, penabulasian data atau informasi dalam proses pengambilan keputusan pada rapat di Dinas Pemadam Kebakaran Kota Bima dinilai sangat sesuai. Berdasarkan variabel penelusuran dan pengumpulan data atau informasi dalam proses dalam pengambilan keputusan, baik penataan data atau informasi, penyederhanaan data atau informasi, pengelompokkan data atau informasi, maupun penabulasian data atau informasi, maka hasilnya sangat sesuai dengan proses pengambilan keputusan dalam organisasi yang profesional.

\section{KESIMPULAN}

Berdasarkan pada pembahasan pada Bab-bab terdahulu, terutama sekali pada bagian Bab Pembahasan Hasil, maka beberapa hal berikut menjadi kesimpulan penelitian ini.

a. Berdasarkan variabel penelusuran dan pengumpulan data atau informasi dalam proses pengambilan keputusan pada Musyawarah Perencanaan Pembangunan, baik penataan data atau informasi, penyederhanaan data atau informasi, pengelompokkan data atau informasi, maupun penabulasian data atau informasi, maka hasilnya sangat sesuai dengan proses pengambilan keputusan dalam organisasi yang profesional.

b. Berdasarkan variabel analisis data dalam proses pengambilan keputusan pada rapat di Dinas Pemadam Kebakaran Kota Bima, baik melakukan seleksi data atau informasi, pemilihan data atau informasi, penyederhanaan data atau informasi, maupun pengabstrakkan data atau informasi, maka rata-rata hasilnya sangat sesuai.

c. Berdasarkan variabel penetapan keputusan dalam proses pengambilan keputusan pada rapat di Dinas Pemadam Kebakaran Kota Bima, baik melakukan pembobotan maupun memilih bobot yang tertinggi atau yang paling mendekati kenyataannya, maka rata-rata hasilnya sangat sesuai.

d. Berdasarkan variabel evaluasi keputusan dalam proses pengambilan keputusan pada rapat di Dinas Pemadam Kebakaran Kota Bima, baik kemanfaatan keputusan, kemungkinan hambatan, kemungkinan menimbulkan konflik, tingkat ketercapaian, akseptabilitas, keterukuran, maupun rasionalitas, maka hasilnya sangat sesuai dengan proses pengambilan keputusan dalam organisasi yang profesional.

\section{Saran-saran}

Dengan melihat kesimpulan di atas, maka ada beberapa saran yang diajukan yakni :

a. Walaupun hasil kaitan dengan berdasarkan variabel penelusuran dan pengumpulan data atau informasi dalam proses pengambilan keputusan pada Musyawarah Perencanaan Pembangunan, baik penataan data atau informasi, penyederhanaan data atau informasi, pengelompokkan data atau informasi, maupun penabulasian data atau informasi, maka 
hasilnya sangat sesuai dengan proses pengambilan keputusan dalam organisasi yang profesional, akan tetapi disarankan untuk tetap dipertahankan hasilnya.

b. Walaupun hasil kaitan dengan berdasarkan variabel analisis data dalam proses pengambilan keputusan pada rapat di Dinas Pemadam Kebakaran Kota Bima , baik melakukan seleksi data atau informasi, pemilihan data atau informasi, penyederhanaan data atau informasi, maupun pengabstrakkan data atau informasi, maka rata-rata hasilnya sangat sesuai, akan tetapi disarankan untuk tetap dipertahankan hasilnya.

c. Walaupun hasil kaitan dengan berdasarkan variabel penetapan keputusan dalam proses pengambilan keputusan pada rapat di Dinas Pemadam Kebakaran Kota Bima , baik melakukan pembobotan maupun memilih bobot yang tertinggi atau yang paling mendekati kenyataannya, maka rata-rata hasilnya sangat sesuai, akan tetapi disarankan untuk tetap dipertahankan dan diusahakan ditingkatkan hasilnya.

d. Walaupun hasil kaitan dengan variabel evaluasi keputusan dalam proses pengambilan keputusan pada rapat di Dinas Pemadam Kebakaran Kota Bima , baik kemanfaatan keputusan, kemungkinan hambatan, kemungkinan menimbulkan konflik, tingkat ketercapaian, akseptabilitas, keterukuran, maupun rasionalitas, sudah sangat sesuai, akan tetapi disarankan untuk tetap dipertahankan dan diusahakan ditingkatkan hasilnya.

\section{DAFTAR PUSTAKA}

Arni, Muhammad, 2005. Komunikasi Organisasi. Bumi Aksara, Jakarta.

Asmara U.Husna, 1982, Pengantar Kepemimpinan Pendidikan, Ghalia Indonesia, Jakarta Timur.

Burhanuddin, 1994, Analisis Adminitrasi Manajemen dan Kepemimpinan Pendidikan, Bumi Aksara, Jakarta.

Cangara, Hafied. 2011. Pengantar Ilmu Komunikasi. Jakarta: PT Rajagrafindo Persada

Creswell. 2008. Metode Penelitian. Jakarta. Sinar Jaya.

Danim, Sudarwan, 2002, Menjadi Peneliti Kualitatif, Cetakan I, Pustaka Setia, Bandung.

DeVito, JA., 2011. Komunikasi Antarmanusia. Maulana A, penerjemah. Wahyu YI, Prihantini Y, Editor. Tangerang Selatan: Karisma Publishing Group.

Effendy, Onong Uchjana, 2003, Ilmu, Teori dan Filsafat Komunikasi, Citra Aditya Bakti, Bandung. -, 2004. Dinamika Komunikasi. Bandung: PT Remaja Rosdakarya

Gaffar, A., 2002, Dasar-dasar Administrasi dan Supervisi Pengajaran, Angkasa Raya, Padang.

Gaspersz, Vincent, 1994, Sistem Informasi Manajemen (Suatu Pengantar), Armico, Bandung.

George R. Terry, 2002, Asas-Asas Menejemen, Alumni, Bandung.

George S. Odiorne, 2002, Keputusan Manajemen Berdasarkan Sasaran, Gramedia, Jakarta.

Gufran, Dkk (Tim Penyusun), 2012, Pedoman Penulisan Karya Ilmiah, Sekolah Tinggi Ilmu Sosial dan Ilmu Politik (STISIP) Mbojo Bima, Bima.

Hadi, Sutrisno, 1984, Statistik 2, Cetakan Ketujuh, Yayasan Penerbit Fakultas Psikologi UGM, Yogyakarta

Hadari Nawawi, dan H.M. Hadani, 2001, Pengantar Sistem Informasi Manajemen, CV.Haji Masagung, Jakarta.

Haer Abdul, 2003, Gaya Kepemimpinan Kepala pada Sekolah Lanjutan Tingkat Pertama Negeri 4 Bolo Kota Bima, Penelitian, STISIP Bima.

Handayaningrat, Soewarno,1994, Pengantar Studi Ilmu Administrasi dan Manajemen, CV.Haji Masagung, Jakarta.

Karjadi, M., 1997, Kepemimpinan, Karya Nusantara, Bandung.

Kartono, Kartini, 2008, Pemimpin dan Kepemimpinan, Rajawali Pres, Jakarta.

Liliweri, Alo. 1991. Memahami Peran Komunikasi Massa Dalam Masyarakat. Citra Aditya Bakti, Bandung. 
Miles, Matthew B dan A. Michael Huberman, 1992, Analisis Data Kualitatif, Cetakan Pertama, UIPress, Jakarta.

Moleong, Lexy J., 1999, Metodologi Penelitian Kualitatif, Cetakan Kesepuluh, Remaja Rosdakarya, Bandung.

Muhajir, Noeng, 1992, Metode Penelitian Kualitatif, Raka Sarasin, Yogyakarta.

Mulyana, Deddy dan Jalaluddin Rakhmat, 2000, Komunikasi Antarbudaya, Remaja Rosdakarya, Bandung.

Mulyana, Deddy 2005, Komunikasi Suatu Pengantar, Remaja Rosdakarya, Bandung.

Papayungan, M.M., Dkk., 2002. Metode Penelitian Ilmu Sosial (Teori dan Praktek), Pusat Studi Kependudukan Universitas Hasanuddin, Ujung Pandang.

Purwanto, M.Ngalim, 2005, Administrasi dan Supervisi Pendidikan, Remaja Rosdakarya, Bandung.

Riswandi. 2009. Ilmu Komunikasi. Yogyakarta: Graha Ilmu 